\title{
The interdependence of coffee futures and spot markets - An econometric analysis
}

\author{
B.N. Pradeepa Babu* and Arun Muniyappa \\ Coffee Board, Bengaluru-560 001, Karnataka, India \\ (Manuscript Received: 03-07-2020, Revised: 08-12-2020, Accepted: 15-01-2021)
}

\begin{abstract}
Coffee is an export-oriented commodity for producing countries, and it is actively traded at international commodity exchange platforms viz., Intercontinental Exchange (ICE), New York and ICE, Europe. This study examines the interdependence of futures and spot markets for coffee in the price discovery mechanism, particularly in the Indian context. The study has considered both the International Coffee Organization (ICO) indicator prices and producers' prices in India's spot prices. The study confirms the existence of a stable long-run relationship between ICE coffee futures and ICO spot prices, implying that both prices react to the same set of market information. While there is an indication of equilibrium or long-run relationship between ICE Coffee futures (New York) and Arabica producer prices (at farm gate level) in India, the same was not true for Robusta coffee. The absence of co-integration between ICE futures prices (London) and Robusta producer prices in India suggested only a short-run relationship between them. The findings of the study conclude with strong evidence that the farm gate prices in India have been caused by the ICE futures markets, declining the contrary.
\end{abstract}

Keywords: Coffee futures exchanges, coffee prices, coffee spot prices, co-integration, econometrics, Granger causality

\section{Introduction}

Coffee is one of the most widely traded tropical agricultural commodity in the world. It is primarily an export-oriented commodity for many producing countries. With over 80 per cent of coffee produced being exported, it serves as a source of export earnings for the producing nations while providing a strong livelihood basis for about 25 million small coffee farmers globally. Thus, it is the key contributor to foreign exchange earnings for nearly 50 producing countries, most of them comprising of developing economies of Central and South America, Africa and Asia (Watson and Achinelli, 2008). Coffee is a major source of income for more than 12 million farms globally, a quarter of which are operated by women (ICO, 2019a and ICO, 2018b). Further, the various factors in the coffee value chain, domestic and overseas, earn economic benefits, be they agents, traders, hullers, curers, roasters, retailers, exporters and importers and their workforce, with an estimated 100 million families depending on the coffee sector (ICO, 2019a).

With coffee production increasing by more than 65 per cent since the 1990s, the producing countries earn around USD 20 billion in exports in a year. The corresponding income of the coffee sector as a whole is estimated to exceed USD 220 billion (ICO, 2019a). Thus it is evident that the value realization for producing countries from the green coffee exports (USD 20 billion) is less than 10 per cent of the total income generated in the coffee retail market (USD 220 billion) ${ }^{1}$. With its lengthy value chain, the several actors and marketing functions such as processing, value addition, storage, traceability etc.,

*Corresponding Author: pradeepa.coffeeboard@gmail.com

${ }^{1}$ Low producers share in consumer rupee is mainly due to consolidation (Brand Market Power) of coffee industry on processing (roasting) side and increased value addition in coffee importing countries (while a low level of value addition in producing countries) resulted in increased profit share of downstream actors. 


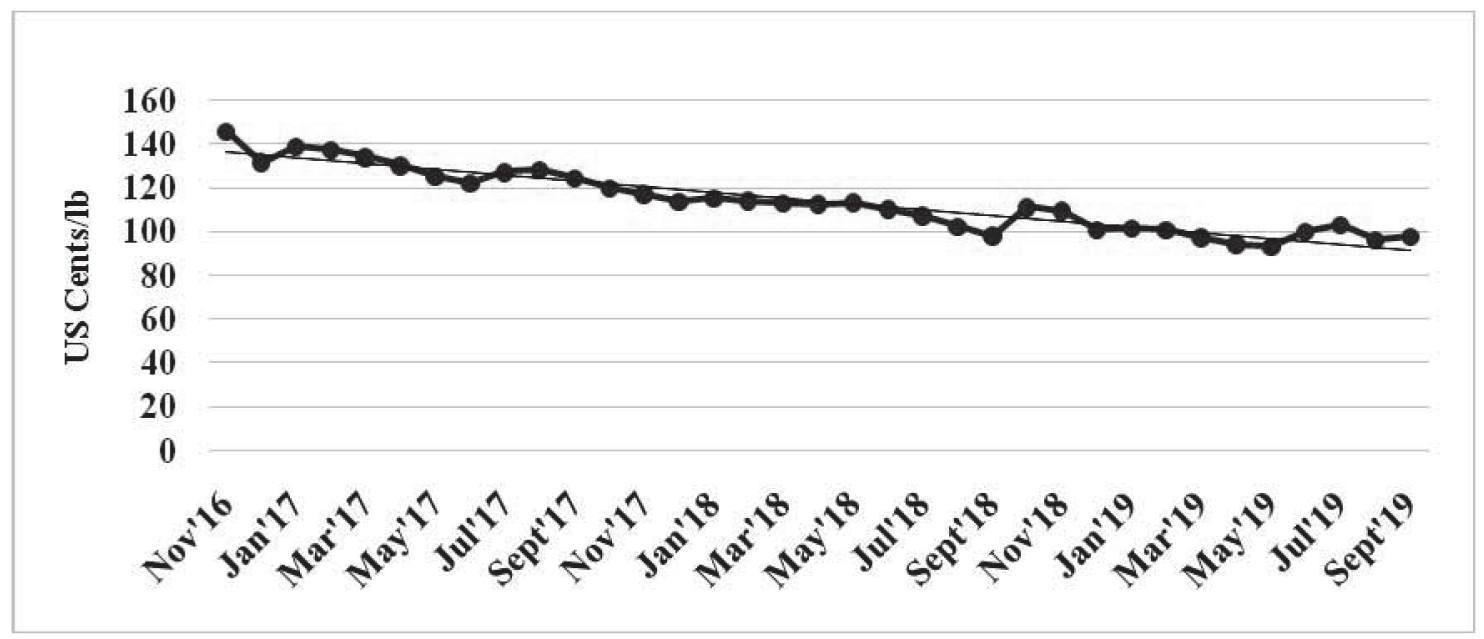

Source: Plotted using data from ICO

Fig. 1. ICO Composite indicator prices US Cents $\mathbf{I b}^{-1}$

escalate the marketing costs. In whatever case, the producers' share in consumer's rupee is considerably low.

Despite significant growth in the global coffee sector, coffee bean prices evidenced a declining trend since November 2016 (Fig. 1). The International Coffee Organization (ICO) indicator prices declined substantially (33\%; a monthly average decline of about $1 \%$, over the past three years) from 145.82 US cents/lb in November 2016 to 97.74 US cents/lb during September 2019. On the contrary, the production costs are increasing due to the increasing wage rate and input costs as economies in the producing countries are growing. Consequently, growers are succumbed to declining income and posing a serious threat to the sustainability of the coffee sector and the coffee supply in the future.

The coffee prices are mainly determined by market forces of demand and supply, particularly production, consumption and stock movements. Demand for coffee being inelastic, its consumption shows little variations to changes in price, as it lacks close substitutes (ICO, 2019a). While coffee consumption is growing steadily at a healthy annual rate of 2 per cent from 2015 to 2019 (ICO, 2019c), there have been various issues affecting coffee production worldwide on the supply-side. Climate change is affecting coffee productivity and eventually affecting its production in most growing nations, including India. As a result, the global coffee market is in persistent disequilibrium created by cycles of imbalance in supply and demand.

At present, the coffee market is in disequilibrium due to cumulative oversupply. The ICO estimated global coffee production in 2018-19 at 168.87 million bags ( $60 \mathrm{~kg}$ each) which exceeded global consumption (164.82 million bags) by 4.05 million bags, a second consecutive year of surplus. The total cumulative surplus of 5.48 million bags for the past two years is attributed to the prevailing low coffee prices (ICO, 2019b).

Since coffee is an export-oriented commodity for the producing countries, the domestic purchase prices of coffee in the producing countries mainly depend on the international price movements. Coffee is actively traded at international commodity exchange. There are two major international commodity exchanges for coffee ${ }^{2}$, each of which effectively acts as a basis to compare coffees of

${ }_{2}^{2}$ It is pertinent to note that in addition to ICE New York and Europe markets, there are a number of smaller coffee futures markets across the world including Singapore (Singapore Commodity Exchange for Robusta coffee) and Brazil (Bolsa de Mercadorias \& Futuros for Arabica coffee). 
different origin and quality. Coffee ' $\mathrm{C}$ ' contract traded on the Intercontinental Exchange (ICE) in New York is the benchmark for Arabica coffee. The Robusta futures contract traded on ICE Europe serves as the standard for Robusta coffee. Here, we restrict to considering these two futures markets for coffee as these are, by far, the two largest (Scholer, 2004).

Futures markets play an important role in transparent price discovery, dissemination and risk transfer (Hall et al., 2006). Coffee is subject to significant price volatility compared to other tropical agricultural commodities like cocoa (Gilbert and Morgan, 2010). These volatile and low coffee prices have an adverse impact on the livelihood of 25 million small coffee growers across the world and 3.73 lakh smallholders in India. The global coffee value chain and the market structure changed dramatically after the deregulation, from monopoly to liberalized markets. Since the liberalization of coffee markets, farm gate prices in the producing countries have been increased but have led to very high volatility. Small coffee growers in developing countries are more vulnerable to the upswings and downswings that happen day to day on international commodity exchange platforms. Consequently, understanding the role of coffee futures markets in determining spot or producers prices has been the subject of significant academic attention (Kaminsky and Kumar, 1990; Morgan et al., 1999; Mohan, 2007).

Against this backdrop, an attempt has been made to understand the relationship between the futures prices (a contractual agreement to purchase the commodity at a future date) and spot prices (current coffee price for immediate delivery) of both Arabica and Robusta coffee.

\section{Materials and methods}

The methodology adopted uses statistical tests to examine the extent of the relationship between ICE coffee future prices and spot prices, both in the long run and short run. The analysis was carried out based on monthly observations of Arabica and Robusta coffee prices from January 1990 to September 2019. This period corresponds to the free-market era, the post-regulated period under the International Coffee Agreements from 1963 to 1989, which were intended to manage global supply to maintain price stability (ICO, 2014). Futures market prices indicate a combined view of buyers and sellers of their expected futures market conditions. Similarly, the ICO produces a set of composite price indices intended to form representative benchmarks for the major types of green coffee (denoting spot prices). Further, these data are often used by coffee authorities to calculate payments to coffee growers in producing countries and are often used as spot prices (Fry et al., 2011), which indicate the current condition of fundamental factors viz., actual demand trend and supply shocks. The Spot price series used in the analysis contains monthly observations of ICO indicator prices of the four groups (Colombian Milds, Other Milds, Brazilian naturals and Robustas), and the futures prices comprise an average of $2^{\text {nd }}$ and $3^{\text {rd }}$ positions ${ }^{3}$ of ICE, New York ' $\mathrm{C}$ ' Contract for Arabica coffee and ICE, Europe for Robusta coffee traded in London.

In addition to the ICO indicator prices being employed to represent the Spot market, the study also used the monthly average farm gate prices in India (sourced from ICO) to examine the relationship between futures and spot prices. Internationally, Indian Arabica coffees are grouped under the 'Other Milds' group, and Robusta coffees from all the producing countries are grouped as 'Robustas'. All the prices are given in US cents/lb. The price series are tested for stationary using the Augmented Dickey-Fuller (ADF) test (Dickey and Fuller, 1981), both with and without a trend. The ADF test is used to test the null hypothesis of nonstationarity against an alternative of stationarity of the price data under consideration. The BreuschGodfrey statistic is used to select the optimum number of lags to ensure the absence of serial correlation in the ADF equation (Greene, 2000). In practice, the following three different forms of ADF

\footnotetext{
${ }^{3}$ Since the coffee standard contracts are traded on exchanges, the delivery date (the final date by which the futures contract for a commodity must be delivered) is chosen from the set of calendar months, called the trading position (For Arabica; March, May, July, September, and December and for Robusta; January, March, May, July, September, November). The month closest to delivery is called first position; the following is the second position and so forth (International Trade Centre, 2011).
} 
equations are required for estimation by the ordinary least square method.

$$
\begin{aligned}
& \Delta y_{t}=\beta_{t} Y_{t-1}+\sum_{i=1}^{k} \gamma \Delta y_{i-1}+\varepsilon_{t} \ldots \ldots \ldots \ldots \ldots \ldots \ldots \ldots . .(E q .1) \\
& \Delta y_{t}=\alpha_{t}+\beta_{t^{\prime}-1}+\sum_{i=1}^{k} \gamma_{i} \Delta y_{t-i}+\varepsilon_{i} \ldots \ldots \ldots \ldots \ldots \ldots \ldots . . .(E q .2) \\
& \Delta y_{t}=\alpha_{t}+\beta_{t^{\prime}-1}+\delta \sum_{t=1}^{k} \gamma_{i} \Delta y_{t-i}+\varepsilon_{t} \ldots \ldots \ldots \ldots \ldots \ldots \ldots . .(E q .3)
\end{aligned}
$$

Where, $\mathrm{t}$ is the time trend, $\mathrm{k}$ represents the number of lags chosen in the model. The null hypothesis of the existence of unit root is $\mathrm{H}_{0} ; \beta=0$, (Eq. 1) is a pure random walk, (Eq. 2) with an intercept term $\alpha_{t}$ and (Eq. 3 ) includes both a constant and a linear time trend, $\delta_{\mathrm{t}}$. This methodology was employed in the study by the International Coffee Organization (ICO, 2018a). In the present study, equations 2 and 3 are used for testing the stationarity of time series price data. In summary, if futures and sport prices are found to be I (1), they can be tested for co-integration.

The conformation that all price series are stationary at I (1) allows proceeding for the cointegration test. The ICE futures prices and spot prices are tested for co-integration by employing the Johansen test. The procedure introduced by Johansen (1991), the null hypothesis of no cointegration, will be tested against the alternative of one co-integrating equation. Johansen co-integration test uses the vector autoregressive (VAR) method, in which all co-integrated series are assumed endogenous. The Johansen tests are likelihood ratio tests as it relies on maximum likelihood method, there are two test statistics viz., 1) Trace test and 2) Maximum Eigen value test. Under the Trace test, the null hypothesis is based on the assumption of no co-integration equation, which needs to be rejected to establish co-integration between the time series variables. The trace test statistic is given below:

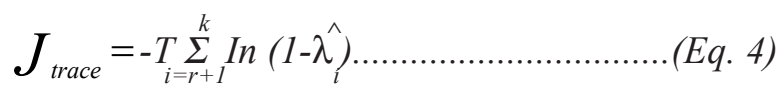

Here $\mathrm{T}$ is the sample size, and $\lambda_{i}^{\wedge}$ is the $\mathrm{i}^{\text {th }}$ largest canonical correlation.
The maximum Eigen value test starts from the null hypothesis of no co-integration equation and tests against a different alternative. The rejecting of the null hypothesis using the maximum Eigen value is slightly different from the trace test. Though both forms are based on the assumption of no cointegration in their null hypothesis, rejecting the null based on the maximum Eigen value implies that there is just a single possible combination of the non-stationary variables to yield in a stationary process. The corresponding test statistic for the maximum Eigen value is given below:

$$
J_{\text {max }}=-T \ln \left(1-\lambda_{r+1}^{\wedge}\right)
$$

The trace test examines the null hypothesis of ' $r$ ' cointegrating vectors against the alternative hypothesis of ' $n$ ' co-integrating vectors. On the other hand, the maximum Eigen value test tests the null hypothesis of ' $r$ ' co-integrating vectors against the alternative hypothesis of ' $\mathrm{r}+1$ ' co-integrating vectors (Hjalmarsson and Österholm, 2007).

Having ensured the presence of a co-integration relationship between the futures and spot prices, the influence/direction of causation (spot to futures or otherwise) in coffee price discovery is examined using the Granger casualty test. In the case of two time-series price variables, futures prices are said to Granger-cause spot prices if spot prices can be better predicted using the histories of both futures prices and spot prices rather than using spot prices alone.

After identifying the requisite properties of the individual price series (lag length and unit root), the presence of Granger causality between ICE futures prices and spot prices is tested by estimating the following unrestricted model:

$$
D \cdot S_{t}^{c}=\alpha_{0}+\sum_{i=1}^{m} \alpha_{i} D \cdot S_{t-i}^{c}+\sum_{i=1}^{m} \beta_{i} F_{t-i}^{c}+\varepsilon_{t} \ldots \text { (Eq. 6) }
$$

Where, $S_{t}^{c}$ is the log of each ICO coffee price indicator (c) at year t, D is the first difference of variable, for example for coffee spot prices: D and D. is the lagged ICE coffee futures prices (New York and Europe) at time t, in its stationary form, $\mathrm{m}$ is 
the optimal lag length. The residual sum of squares is recoded (ESSu) after estimating the model, then estimated with the following restricted model:

$D \cdot S_{t}^{c}=\alpha_{0}+\sum_{i=1}^{m} \alpha_{i} D \cdot S_{t-i}^{c}+\varepsilon$

The residual sum of squares (ESSr) is recorded after estimating the restricted model.

Granger causality test is performed by calculating the F-statistic and comparing it to the F-critical value at a 5 per cent level of significance. The F statistic computed as follows:

$$
\mathrm{F}=\frac{\left(E S S_{r}-E S S_{u}\right) / m}{\frac{E S S_{u}}{n-1-m}}
$$

where, $\mathrm{m}$ is the optimal lag length, $\mathrm{n}$ is the number of observations ' $\mathrm{m}$ ' and ( $\mathrm{n}-1-\mathrm{m})$ is the degrees of freedom.

The Granger causality test compares the residual sum of squares of both unrestricted and restricted econometric model. The null hypothesis of no causality between futures and spot prices is tested against the alternative hypothesis of its existence. The null hypothesis can be rejected when the estimated $\mathrm{F}$ statistic is greater than the $\mathrm{F}$ critical value and there is evidence of the existence of causality between two price series. This methodology was employed in the study "Futures markets: the role of non-commercial traders" by the International Coffee Organization (ICO, 2018C).
In the present study, two econometric approaches were employed to study the causal interaction between coffee futures and spot prices: the Johansen co-integration test, to ascertain the presence of long-run or equilibrium relationship, and the Granger causality test to examine the shortrun dynamics.

\section{Results and discussion}

\section{Stationary test for different price series - ADF}

The estimated results of the ADF test are presented in Table 1 and Table 2. Table 1 represents results pertaining to equation 2 (with intercept but no time trend).

The second column of the table represents the ADF test results for individual price series under study in level, while the third column shows the results for the first difference of price series under study. Both futures prices (ICE New York and ICE Europe) and spot prices (Colombian milds, Other milds, Brazilian naturals, Robustas and farm gate price paid to growers in India) are non-stationary in level but stationary after the first difference (Table 1). Further, Table 2, representing the ADF test (equation 3 ) with constant and time trend, indicates that the spot prices and futures prices are stationary at the first-order difference. Although the ICE New York futures market price is stationary in the level itself, its first difference is considered to make the two series (both futures and spot) have the same order of integration.

The estimated results reveal that the ADF test cannot reject a null hypothesis that the price series

Table 1. ADF test results, including constant but no time trend (Estimates of equation-2)

\begin{tabular}{lcccc}
\hline Future/spot prices & \multicolumn{2}{c}{ Test statistic } & \multicolumn{2}{c}{ P-value } \\
\cline { 2 - 5 } & Level & First difference* & & Level \\
& -2.98 & -10.61 & 0.04 & 0.00 \\
& -2.43 & -19.23 & 0.13 & 0.00 \\
ICE New York future market prices & -2.70 & -15.78 & 0.07 & 0.00 \\
Colombian milds group indicator prices & -2.90 & -10.35 & 0.05 & 0.00 \\
Price paid to Arabica coffee growers in India & -2.28 & -13.44 & 0.18 & 0.00 \\
ICE Europe future market prices & -3.13 & -9.75 & 0.03 & 0.00 \\
Robustas & -2.82 & -9.93 & 0.06 & 0.00 \\
Price paid to Robusta coffee growers in India & -1.99 & -17.20 & 0.29 & 0.00 \\
\hline
\end{tabular}

*statistical significance at $5 \%$ 
Table 2. ADF test results, including constant and trend (Estimates of equation-3)

\begin{tabular}{|c|c|c|c|c|}
\hline \multirow[t]{2}{*}{ Future/spot prices } & \multicolumn{2}{|c|}{ Test statistic } & \multicolumn{2}{|c|}{ P-value } \\
\hline & Level & First difference* & Level & First difference* \\
\hline ICE New York future market prices & -3.14 & -10.60 & 0.10 & 0.00 \\
\hline Colombian milds group indicator prices & -2.50 & -19.21 & 0.33 & 0.00 \\
\hline Other milds group indicator prices & -2.97 & -15.76 & 0.14 & 0.00 \\
\hline Brazilian naturals group indicator prices & -3.06 & -10.34 & 0.12 & 0.00 \\
\hline Composite group indicator prices & -2.86 & -10.33 & 0.18 & 0.00 \\
\hline Price paid to Arabica coffee growers in India & -2.80 & -13.42 & 0.20 & 0.00 \\
\hline ICE Europe future market prices (Robustas) & -3.21 & -9.74 & 0.08 & 0.00 \\
\hline Robustas & -2.92 & -9.92 & 0.16 & 0.00 \\
\hline Price paid to Robusta coffee growers in India & -2.37 & -17.18 & 0.40 & 0.00 \\
\hline
\end{tabular}

*statistical significance at 5\%

are non-stationary at a significance level of 5 per cent. However, in the first difference, both futures and spot price series were found to be stationary and, therefore, were integrated of order one, i.e. I (1).

\section{Co-integration test}

Johansen co-integration test is employed to test the existence of the long-run relationship between the futures and spot price series. Given that all the price series viz., ICE New York and ICE Europe futures prices and spot prices (represented by indicator prices of Colombian Milds, Other Milds, Brazilian naturals and Robustas and the farm gate price paid to growers in India) in the study are integrated of the same order I (1), the analysis proceeded with Johansen co-integration test to examine whether the two price series co-integrated. Table 3 represents the co-integration test results between ICE New York and Europe futures price series and ICO indicator (spot) price series ${ }^{4}$. Table 4 indicates the co-integration test results between ICE New York and Europe Futures prices and farm gate prices in India. The number of equations in the analysis depends on the number of price series used. The maximum number of equations could be the number of price series minus one. Since we have only two price series, the maximum number of equations we can have is only one. In all the cases (futures and spot combinations), both Trace and maximum Eigen value tests show the existence of one co-integrating equation. Thus, as per both the tests, the null hypothesis of no co-integration can be rejected in all cases, at a five per cent significance level (the p-value below 5\% indicates this). The estimated results of Johansen's test indicate the presence of one co-integrating equation, which shows the existence of a stable long-run relationship between the ICE coffee futures and spot prices viz., Colombian Milds, Other Milds, Brazilian naturals and Robustas. Thus they share a common stochastic factor and react to the same set of information. This means that any deviations from this long-run relationship will be corrected. Statistically, the existence of co-integration between two-time series variables rules out non-causality between them. It supports the assumption of a stable long-run or equilibrium relationship between futures and spot prices.

Nevertheless, in the case of the two ICE coffee futures markets, the existence of co-integration is observed at a 5 per cent level of significance as per Trace statistic. Still, no co-integration has been found as per the maximum Eigen value statistic. Trace Statistic results of the existence of cointegration between two coffee futures markets are

${ }^{4}$ Since the terms spot/indicator prices and farm gate prices sound very similar, it is important to distinguish between them. The Indicator prices, published on daily basis by International Coffee Organization, indicates the spot/cash prices quoted individually for four main types of coffee (Colombian Milds, Other Milds, Brazilian naturals and Robustas) in respective markets, calculated by computing a weighted average of coffee prices, after considering many factors such as ex-dock, prompt shipment prices etc. On the other hand, farm gate prices represent the prices prevailed at farm gate in producing countries, in our study, it is Indian farm gate coffee prices. 
Table 3. Co-integration test results of ICE futures prices and ICO indicator prices (spot prices)

\begin{tabular}{|c|c|c|c|c|c|}
\hline \multirow[t]{2}{*}{ Price series } & \multirow{2}{*}{$\begin{array}{c}\text { No. of } \\
\text { co-integration } \\
\text { equations }\end{array}$} & \multicolumn{2}{|c|}{ Trace test } & \multicolumn{2}{|c|}{ Max eigen value } \\
\hline & & $\begin{array}{c}\text { Test } \\
\text { statistic }\end{array}$ & p-value & $\begin{array}{c}\text { Test } \\
\text { statistic }\end{array}$ & p-value \\
\hline \multirow[t]{2}{*}{ ICE New York future prices and Colombian milds } & 0 & $22.89 *$ & 0.00 & $16.11 *$ & 0.03 \\
\hline & 1 & $6.77 *$ & 0.01 & $6.77 *$ & 0.01 \\
\hline \multirow[t]{2}{*}{ ICE New York future prices and other milds } & 0 & $21.85 *$ & 0.00 & $15.39 *$ & 0.03 \\
\hline & 1 & $6.46 *$ & 0.01 & $6.46 *$ & 0.01 \\
\hline \multirow[t]{2}{*}{ ICE New York future prices and Brazilian naturals } & 0 & $20.92 *$ & 0.01 & $14.46^{*}$ & 0.05 \\
\hline & 1 & $6.45 *$ & 0.01 & $6.45 *$ & 0.01 \\
\hline \multirow[t]{2}{*}{ ICE Europe future prices and Robustas } & 0 & $22.10 *$ & 0.00 & $18.20 *$ & 0.01 \\
\hline & 1 & $3.90 *$ & 0.05 & $3.90 *$ & 0.05 \\
\hline \multirow[t]{2}{*}{ ICE New York future price and ICE Europe futures prices } & 0 & $15.84 *$ & 0.04 & 9.01 & 0.28 \\
\hline & 1 & $6.83 *$ & 0.01 & $6.83 *$ & 0.01 \\
\hline
\end{tabular}

*statistical significance at $5 \%$

in line with the earlier study conducted by Karbuz and Jumah (1995). The study tested the presence of co-integration between two coffee future markets (ICE New York and ICE Europe) and also tested the law of one price for coffee ICE futures markets traded in New York and London. The authors found the existence of co-integration between them and interpreted it as indicative of a state of perfect competition between the two coffee ICE futures markets.

However, the hypothesis of the Law of one price is rejected due to product differentiation between the two major coffee types, Arabica (traded in ICE New York futures market) and Robusta (traded in ICE Europe futures market). Further, based on the Trace and maximum Eigen value statistics, the null hypothesis of the existence of no co-integration relationship between ICE New York futures prices and farm gate prices of Arabica coffee in India can be rejected. However, the null hypothesis of the existence of no co-integration relationship between ICE Europe futures prices and farm gate prices of Robusta coffee in India cannot be rejected based on both Trace and maximum Eigen value statistics (Table 4).

The study results are in line with the study conducted by Rajaraman (1986), wherein the efficiency of futures markets for coffee is analyzed and concluded that the coffee futures market in New York is efficient but rejects this hypothesis for the London-based market (ICE Europe). The absence of co-integration (in the case of Robustas) suggests that there might be only a short-run relationship between two-time series variables.

Co-integration between two-time series is not just an indication of the presence of a long-run or equilibrium relationship between the variables caused by market forces. Still, there may exist a causal relationship among them which is examined using the Granger causality test.

Table 4. Co-integration test results of ICE future prices and farm gate coffee prices in India

\begin{tabular}{|c|c|c|c|c|c|}
\hline \multirow[t]{2}{*}{ Price series } & \multirow{2}{*}{$\begin{array}{c}\text { No. of } \\
\text { co-integration } \\
\text { equations }\end{array}$} & \multicolumn{2}{|c|}{ Trace test } & \multicolumn{2}{|c|}{ Max. eigen value } \\
\hline & & $\begin{array}{c}\text { Test } \\
\text { statistic }\end{array}$ & p-value & $\begin{array}{c}\text { Test } \\
\text { statistic }\end{array}$ & p-value \\
\hline \multirow[t]{2}{*}{ ICE New York futures prices and Arabica } & 0 & $22.51 *$ & 0.00 & $17.34 *$ & 0.02 \\
\hline & 1 & $5.17 *$ & 0.02 & $5.17 *$ & 0.02 \\
\hline \multirow[t]{2}{*}{ ICE Europe future prices and Robusta } & 0 & 13.45 & 0.10 & 10.23 & 0.20 \\
\hline & 1 & 3.21 & 0.07 & 3.21 & 0.07 \\
\hline
\end{tabular}

*statistical significance at $5 \%$ 


\section{Granger causality test}

If two-time series variables are co-integrated, there may exist a Granger causality between them (Miller, 1991; Miller and Russek, 1990). While the co-integration analysis was necessitated by testing the long-run relationship between the price series, it does not indicate the direction of causation. The question of whether spot prices cause futures prices or futures prices cause spot prices are unanswered. The Granger causality test between them would indicate the price in one market, would commonly be found to Granger cause the price in the other market, and/or vice versa (Fackler and Goodwin, 2001).

Thus, the Granger causality test provides additional evidence of whether and in which direction price transmission occurs between two markets (Paul and Sinha, 2015). The earlier studies (Bessembinder and Seguin, 1992; Figlewski, 1981; Kocagil and Shachmurove, 1998; Kyriacou and Sarno, 1999) related to the Granger causality test between futures and spot market reported bidirectional causality between futures and spot markets. The present study examines whether a similar relationship exists between coffee futures and spot markets. The results of Granger causality tests are extremely sensitive to the lag condition (Thornton and Batten, 1984). It should be noted here that the Granger causality results may vary for the different number of lags (Paul and Sinha, 2015). Too few lags indicate a biased test due to residual auto-correlation, and too many lags allow for potentially spurious rejections of the null hypothesis (Lütkepohl, 2005). The optimum lag for the Granger causality test is selected based on the lowest information criteria. In the present study, it is found that the Akaike Information Criterion (AIC) values are minimum at lag two to four (for different spot prices). Accordingly, a specific lag length of two to four is used for testing the Granger causality.

In the case of Colombian milds and other milds, there is causality in both directions (significant $p$-value for both directions of causation). Thus, the analysis indicates a strong interdependence between coffee futures and spot prices (Colombian milds and other milds). In the case of Brazilian naturals, there exists a unidirectional relationship of the spot prices ganger causing futures prices, indicating local producer prices in Brazil seem to incorporate new market information faster than the New York futures market (Table 5). Brazil is the largest coffee producer globally; the influence of Brazilian spot price on futures price is evident. The existence of sufficiently liquid exchange ${ }^{5}$ and strong domestic consumption in Brazil add to such prominent causation (ICO, 2018a). Study results further

Table 5. Granger causality between coffee future prices and ICO indicator prices (spot prices)

\begin{tabular}{|c|c|c|c|}
\hline Price series & Null hypothesis & F-statistic & p-value \\
\hline ICE New York & Colombian Milds does not Granger cause ICE New York futures prices & $5.26^{*}$ & 0.01 \\
\hline $\begin{array}{l}\text { Futures prices and } \\
\text { Colombian Milds }\end{array}$ & ICE New York Future Prices does not Granger cause Colombian milds & $9.87 *$ & 0.00 \\
\hline ICE New York & Other milds do not Granger cause ICE New York futures prices & $4.09 *$ & 0.02 \\
\hline $\begin{array}{l}\text { futures prices and } \\
\text { other milds }\end{array}$ & ICE New York futures prices do not Granger cause other milds & $3.94 *$ & 0.02 \\
\hline $\begin{array}{l}\text { ICE New York } \\
\text { futures prices and }\end{array}$ & Brazilian naturals do not Granger Cause ICE New York futures prices & $3.24 *$ & 0.04 \\
\hline Brazilian naturals & ICE New York futures prices do not Granger cause Brazilian naturals & 1.12 & 0.33 \\
\hline ICE Europe & Robustas does not Granger cause ICE Europe futures prices & 2.06 & 0.09 \\
\hline $\begin{array}{l}\text { futures prices } \\
\text { and Robustas }\end{array}$ & ICE Europe futures prices do not Granger cause Robustas & $3.42 *$ & 0.01 \\
\hline ICE New York & ICE Europe does not Granger cause ICE New York & 0.29 & 0.88 \\
\hline $\begin{array}{l}\text { futures market and } \\
\text { ICE Europe futures } \\
\text { market }\end{array}$ & ICE New York futures does not Granger cause ICE Europe futures & 0.41 & 0.80 \\
\hline
\end{tabular}

*statistical significance at 5\% 
revealed that the interdependence between the coffee futures and spot market might not be restricted to the unidirectional flow of information from futures to spot market. It could be in the opposite direction as well. The results of the study also revealed that Brazil, with the giant share in world coffee production, is the price maker in the international market.

Further, there exists a unidirectional relationship between ICE Europe and Robustas, indicating that, Robusta spot market remains influenced by ICE Europe coffee futures markets to a greater extent. The study results are in consonance with the study conducted by Fry et al. (2011). Granger causality test between two ICE coffee futures markets indicates a limited possibility of running causality from one to another, as they pertain to entirely different coffees (Arabicas and Robustas).

Coming to the causality test (Table 6), the ICE New York futures prices Granger cause farm gate prices of Arabica coffee in India. Although the Johansen test results rule out co-integration between ICE Europe futures prices and farm prices of Robusta coffee in India, there is a unidirectional relationship of the ICE Europe futures prices Ganger cause farm gate prices of Robusta coffee in India. Therefore, there is feedback from ICE futures prices to spot prices, leading to a price discovery mechanism, providing a sound basis for coffee production and marketing decisions of coffee growers in India. Thus, the coffee ICE futures markets play a dominant role in discovering farm gate coffee prices in India. The study results are in consonance with the study conducted by Fortenbery and Zapata (2004), which indicated a close relationship between ICE New York coffee futures prices and cash export prices in Guatemala Honduras.

Contrary to Brazil, India, with a mere 3.5 per cent share in world coffee production, does not significantly influence international coffee prices. Hence, we are basically 'price takers' rather than 'price influencers'. Therefore, most of the times, growers sold their coffee at a price that has nothing to do with production costs. This indicates that although the existing coffee futures market system is well-intended for bringing efficiency in the global coffee trade, it has failed to help the growers in the high cost producing countries like India ${ }^{6}$. While Indian coffee growers are already struggling with the rising input costs and erratic weather patterns, the current market pricing mechanism does not compensate the production cost (especially in the case of Arabica coffee) on the one hand and the conservation efforts of shade coffee growers on the other. Thus, there is a strong necessity for evolving a more efficient market pricing system that links

Table 6. Granger causality between coffee futures prices and farm gate coffee prices in India

\begin{tabular}{|c|c|c|c|}
\hline Price series & Null hypothesis & F-statistic & p-value \\
\hline ICE New York futures & Farm gate prices of Arabica coffee in India does not Granger cause & & \\
\hline prices and the price paid & ICE New York futures prices & 1.82 & 0.16 \\
\hline to coffee growers & ICE New York futures prices do not Granger cause farm gate price of & & \\
\hline (Arabica) in India. & Arabica coffee in India & $9.53^{*}$ & 0.00 \\
\hline ICE Europe Futures Prices & Price Paid to Coffee Growers (Robusta) in India does not Granger cause & & \\
\hline and farm gate prices of & ICE Europe Futures Prices & 0.79 & 0.54 \\
\hline Robusta coffee in India & $\begin{array}{l}\text { ICE Europe futures prices do not Granger cause price paid to coffee } \\
\text { growers (Robusta) in India }\end{array}$ & $8.14^{*}$ & 0.00 \\
\hline
\end{tabular}

${ }_{5}^{5}$ Brazil's functional Brasil Bolsa Balcão S.A., formerly BM\&FBOVESPA futures exchange is more liquid and deeper with higher number of trades and turnover (Avdjiev et al, 2010; Kaltenbrunner, 2010 and Fritz and Plates, 2014).

${ }^{6}$ Brazil and Vietnam are the low cost producing countries due to their high productivity which is attributed to adoption of intensive production model with mechanization. While, other coffee producing countries like India are high cost producing countries due to low productivity levels which is attributed to predominance of small holders, hilly terrain hindering mechanization, poor economic conditions of the coffee growers to adopt intensive cultivation practices, changing climatic conditions and increased production costs. 
coffee prices to production cost and independent of outside forces.

\section{Conclusion}

The findings of the study proved that the presence of co-integration between coffee futures and spot prices, indicating that both the price series share a common stochastic factor and react to the same set of market information. Yet again, the Brazilian spot coffee market to influence ICE future prices, New York (while the contrary was not holding good) reiterates the dominance of the giant producer even in the international market platform. Thus, Brazil's coffee production and exports play an important role in setting the benchmark for coffee prices at the International level. Further, the econometric analysis of the role of the ICE coffee futures market in the price discovery mechanism at the farm gate level in India indicated that ICE New York and Europe coffee futures market plays a prominent role in the price discovery process for Indian coffees. The study points out that though the futures Market intends to develop an efficient pricing mechanism since India is only a small supplier to the International market, the costing of producers does not have consideration in price setting. In an economic context, though we say that the prices are determined by market demand and supply considerations since the emerging efficient producers like Brazil and Vietnam grow coffee in open conditions with intensive cultivation practices, Indian growers stand at a losing end. This is because, Indian coffee being shade-grown in ecologically sensitive zones of Western Ghats (one of the biodiversity hotspot in the World), has a lower yield. Thus, a strong need for evolving an improved pricing mechanism to consider Indian conservation efforts to offer higher premium prices is essential. Such efforts would help in promoting the conservation efforts of small coffee growers of India.

\section{References}

Avdjiev, S., Upper and Von Kleist, U.V. (2010). Highlights of International Banking and Financial Market Activity. BIS Quarterly Review. Retrieved on $17^{\text {th }}$ April, 2020. (https:/ /www.bis.org/publ/qtrpdf/r_qt1012b.pdf).

Bessembinder, H., and Seguin, P. 1992. Futures-trading activity and stock price volatility. Journal of Finance 47: 2015-2034.
Dickey, D.A., and M.A. Fuller. 1981. Likelihood ratio statistics for autoregressive time series with a unit root. Econometrica, 49: 1057-1072.

Fackler, P.L. and Goodwin, B.K. 2001. Spatial price analysis. In: Handbook of Agricultural Economics, Vol. 1, Part 2, Elsevier pp. 971-1024.

Figlewski, S. 1981. Futures trading and volatility in the GNMA market. Journal of Finance 36: 445-456.

Fortenbery, T.R. and Zapata, H.O. 2004. Developed speculation and under developed markets - The role of futures trading on export prices in less developed countries. European Review of Agricultural Economics 31: 451-471.

Fry, M.J., Lai, B. and Rhodes, M. 2011. The Interdependence of Coffee Spot and Futures Markets. International Network for Economic Research. Retrieved on $13^{\text {th }}$ April, 2020. (https://pdfs.semanticscholar.org/2b09/fa08b3aa 31a6dcde4697e93fc54018922ce9.pd).

Fritz, B., and Prates, D. (2014). The new IMF approach to capital account management and its blind spots: Lessons from Brazil and South Korea. International Review of Applied Economics. 28: 210-239.

Gilbert, C. L. and Morgan, C. W. 2010. Has food price volatility risen? In: Philosophical Transactions of the Royal Society B: Biological Sciences 365 (1554): 3023-3034.

Greene, W. H. 2000. Econometric Analysis, New Jersey: Prentice-Hall, Inc.

Hall, A.D., Kofman, P. and Manaster, S. 2006. Migration of price discovery in semi regulated derivatives markets. Journal of Futures Markets 26: 209-241.

Hjalmarsson, E. and Osterholm, P. 2007. Testing for cointegration using the Johansen methodology when variables are near-integrated. IMF Working Paper, 141, pp. 1-19. Retrieved on: 01 ${ }^{\text {st }}$ February, 2020. (https:// www.imf.org/external/pubs/ft/wp/2007/wp07141.pdf).

ICO (2011). Relationship between coffee prices in physical and futures markets. International Coffee Organization. Retrieved on $13^{\text {th }}$ February, 2020. (http://www.ico.org/ documents/icc-107-4e-prices-markets.pdf).

ICO (2019a). Coffee Development Report- Growing for prosperity Economic viability as the catalyst for a sustainable coffee sector. International Coffee Organization.

ICO (2019b). Coffee Market Report, September, 2019. International Coffee Organization. Retrieved on $9^{\text {th }}$ January, 2020. (http://www.ico.org/documents/cy201819/cmr-0919-e.pdf).

ICO (2019c). Coffee Market Report, November, 2019. International Coffee Organization. Retrived on $6^{\text {th }}$ January, 2020.(http://www.ico.org/documents/cy 201920/cmr-1119-e.pdf). 
ICO (2018a). The role of the coffee futures market in discovering prices for Latin American producers. International Coffee Organization Report. Retrieved on $12^{\text {th }}$ January, 2020. (http://www.ico.org/documents/ cy2017-18/icc-122-5e-price-discovery.pdf_).

ICO (2018b). Gender Equality in Coffee Sector- An insight report. International Coffee Organization. Retrieved on $30^{\text {th }}$ December, 2019. (http://www.ico.org/documents/ cy2017-18/icc-122-11e-gender-equality.pdf).

ICO (2018c). Futures markets: the role of non-commercial traders. International Coffee Organization. Retrieved on $16^{\text {th }}$ December, 2019. (http://www.ico.org/documents/ cy2018-19/Restricted/icc-124-5e-futures-markets.pdf).

ICO (2014). World coffee trade (1963 - 2013): A review of the markets, challenges and opportunities facing the sector. International Coffee Organization. Retrieved on $30^{\text {th }}$ January (http://www.ico.org/news/icc-111-5-r1eworld-coffee-outlook.pdf).

International Trade Centre. 2011. The Coffee Exporter's Guide. 3rd ed. Geneva. Retrieved on $13^{\text {th }}$ February, 2020. (http:/ /www.intracen.org/The-Coffee-Exporters-Guide-ThirdEdition/).

Johansen, S. 1991. Estimation and hypothesis testing of cointegration vectors in Gaussian vector autoregressive. Econometrica 59(6): 1551-1580.

Kaminsky, G. and Kumar, M.S. 1990. Efficiency in commodity futures markets. IMF Staff Papers 37: 670-699.

Kaltenbrunner, A. 2010. International Financialization and Depreciation: The Brazilian Real in the International Financial Crisis. Competition and Change, 14(3-4): 294-321.

Karbuz, S., and Jumah, A. 1995. Co-integration and commodity arbitrage. Agribusiness 11: 235-243.

Kocagil, A.E. and Shachmurove, Y. 1998. Return-volume dynamics in futures markets. Journal of Futures Markets 18: $399-426$.

Kyriacou, K. and Sarno, L. 1999. The temporal relationship between derivatives trading and spot market volatility in the UK: Empirical analysis and Monte Carlo evidence. Journal of Futures Markets 19: 245-270.

Lütkepohl. 2005. New introduction to multiple time series analysis: Retrieved on 07 April 2020 (https// www.springer.com/de/book/9783540401728).

Miller, S.M. 1991. Monetary Dynamics: An application of cointegation and error-correction modeling. Journal of Money, Credit and Banking 23: 139-54.

Miller, S.M. and Russek F.S. 1990. Co-integration and error correction modes: temporal causality between government taxes and spending. Southern Economic Journal 57: 221-29.

Mohan, S. 2007. Market-based price-risk management for coffee producers. Development Policy Review 25: 333-354.

Morgan, C. W., Rayner, A. J. and Vaillant, C. 1999. Agricultural futures markets in LDCs: A policy response to price volatility? Journal of International Development 11: 893-910.

Paul, R.K. and Sinha, K. 2015. Spatial market integration among major coffee markets in India. Journal of the Indian Society of Agricultural Statistics 69(3): 281-287.

Rajaraman, I. 1986. Testing the rationality of futures prices for selected ldc agricultural exports. The Journal of Futures Markets 6: 523-540.

Scholer, M. 2004. Bitter or better future for coffee producers? International Trade Forum (2), International Trade Center. Retrieved on 04 ${ }^{\text {th }}$ April, 2020. (http:// www.tradeforum.org/Bitter-or-Better-Future-for-CoffeeProducers/).

Thornton, D.L. and D.S. Batten.1984. Lag length selection and tests for Granger causality between money and income. Journal of Money, Credit and Banking 17(2): 164-178.

Watson, K. and Achinelli, M. L. 2008. Context and Contingency: The coffee crisis for conventional smallscale coffee farmers in Brazil. The Geographical Journal 174(3): 223-234; (https://doi.org/10.1111/j.14754959.2008.00277.x). 